\title{
Physical properties of pre-crystallized mixtures of cocoa butter and cupuassu fat
}

\author{
By L. B. Quast, ${ }^{a, *}$ V. Luccas ${ }^{b}$ and T.G. Kieckbusch ${ }^{c}$
}

\author{
${ }^{a}$ School of Food Engineering, Ponta Grossa State University (UEPG), Ponta Grossa, \\ Paraná, Campus Uvaranas, Brazil \\ ${ }^{b}$ Institute of Food Technology (ITAL), Campinas, São Paulo, Brazil \\ ${ }^{c}$ School of Chemical Engineering, University of Campinas (UNICAMP), Campinas, \\ São Paulo, Brazil. \\ ( ${ }^{*}$ Corresponding author: lbquast@uepg.br)
}

\section{RESUMEN}

Propiedades físicas de mezclas pre-cristalizadas de manteca de cacao y grasa de cupuassu.

Se han determinado las características físicas de mezclas binarias pre-cristalizadas de manteca de cacao (mezcla de Bahia + Indonesia) con 5, 10, 15, 20, 25 y $30 \%(\mathrm{~m} / \mathrm{m})$ de grasa de cupuassu. La pre-cristalización se ha efectuado a escala de laboratorio utilizando un reactor de vidrio con camisa (700mL) con agitación. Las muestras fueron analizadas mediante calorimetría diferencial de barrido, difracción de rayos$\mathrm{X}$, contenido en grasa solida y tensión de ruptura. Los valores de tensión de ruptura de las mezclas pre-cristalizadas disminuyeron con la incorporación de grasa de cupuassu, siendo este comportamiento observado también para el punto de fusión. Después de la pre-cristalización, manteca de cacao y grasa de cupuassu confirmaron la presencia de polimorfismo $\beta$, por medio de análisis de difracción de rayos-X. La adición de hasta $30 \%$ de grasa de cupuassu en la manteca de cacao no afecta de modo significativo en las propiedades físicas cuando son comparadas con la manteca de cacao pura.

PALABRAS CLAVE: Atemperado o pre cristalización Contenido de gordura sólida - Difracción de rayos- $X$ - Grasa de cupuassu - Manteca de cacao - Mezcla binaria de grasas - Tensión de ruptura.

\section{SUMMARY}

Physical properties of pre-crystallized mixtures of cocoa butter and cupuassu fat.

The physical characteristics of pre-crystallized binary mixtures of cocoa butter (Bahia + Indonesian blend) and 5, 10, $15,20,25$ and $30 \%(w / w)$ cupuassu fat were determined. Precrystallization was carried out using a lab-scale agitated jacket vessel reactor $(700 \mathrm{~mL})$. Samples were submitted to differential scanning calorimetry and X-Ray diffraction. The solid fat content and rupture force were also quantified. The snap values of the crystallized mixture decreased with an increase in the amount of alternative fat. A similar trend was observed with respect to the melting point values. The cocoa butter and cupuassu fat X-ray diffraction patterns confirmed the predominant formation of the $\beta$ polimorph. The addition of up to $30 \%$ cupuassu fat did not significantly affect the values of the physical properties when compared to pure cocoa butter.

KEY-WORDS: Binary mixture of fats - Cocoa butter Cupuassu fat - Snap test - Solid fat content - Tempering - X-ray diffraction.

\section{INTRODUCTION}

Cocoa butter, milk fat and alternative fats constitute the continuous phase in chocolate production and are therefore responsible for the dispersion of the other constituents. Cocoa butter is responsible for the functional attributes in chocolate products, such as hardness at room temperature and pleasant mouth feeling due to melting at body temperature. It contains three main fatty acids: palmitic $(P)$, stearic $(S)$ and oleic (O) acids. Practically all oleic (unsaturated) acid is esterified at the sn-2 position of the glycerol molecule so that more than $75 \%$ of the total triacylglycerols (TAGs) are 1,3-dipalmitoyl-2-oleoylglycerol (POP), 1-palmitoyl-2-oleoyl-3-stearoylglycerol (POS) and 1,3-distearoyl-2-oleoylglycerol (SOS) (Minifie, 1989).

Triacylglycerols display a complex polymorphic behavior, strongly influenced by momentum, heat and mass transfer during crystallization. Polymorphic crystallization is primarily determined by the rate of nucleation, being governed by thermodynamic and kinetic factors. Depending on the cooling rate and agitation level, triacylglycerols appear in various crystal lattices: $\alpha$ (hexagonal sub-cell), $\beta$ ' (orthorhombic sub-cell) and $\beta$ (triclinic sub-cell). The three polymorphs are based on subcell structures which define cross-sectional packing modes of the zigzag aliphatic chain. Each polymorph has a unique melting point and crystal structural properties (Piska et al., 2005; Martínez et al., 2007).

During the manufacturing of chocolate, a proper pre-crystallization or tempering protocol is essential before molding and cooling in order to enhance the stability of the product. The tempering process induces the formation of beta nuclei crystals which are thermodynamically more stable. Properly tempered chocolates have more adequate melting properties and retard the appearance of fat bloom, a grayish white film on the surface of the chocolate (Wille and Lutton, 1966; Maleky and Marangoni, 2008).

Cupuassu (Theobroma grandiflorum Schumann) is a native fruit of the Amazon region, botanically related to cacao ( $T$. cacao L.). Among the Theobroma species, cupuassu has the largest fruit. The fresh seeds contain about $84 \%$ moisture and 
the fat content is approximately $60 \%$ of the dry weight. Cupuassu has found applications in the food, pharmaceutical and chemical industries and the cupuassu fat can be used as an alternative fat substitute for cocoa in chocolate production (Gilabert-Escrivá et al., 2002; Lannes et al., 2003; Medeiros et al., 2006). Just like cocoa, cupuassu seeds can be fermented and dried to obtain cupuassu liquor, which is used to elaborate a Brazilian product, "cupulate", with has nutritional and sensorial characteristics that are very close to chocolate (Oliveira et al., 2004).

Studies reported by Silva et al., (2009), using differential scanning calorimetry, concluded that the polymorphic behavior of cupuassu fat is similar to that of cocoa butter with predominance to crystallization of the beta form.

The sensory attributes of some foods rich in lipids such as chocolates and margarines depend on the structure created by the crystal network. The physical properties of oils and fats such as cocoa butter have been studied using differential scanning calorimetry, solid fat content and X-ray diffraction (Lannes et al., 2003, Czerniak et al., 2005). The solid fat content is used to indicate the physical attributes of fats like its hardness (Himawan et al., 2006). Fats with low solid fat content when used in chocolate manufacturing can result in soft products (Lannes et al., 2003).

$\mathrm{X}$-ray diffraction is a suitable technique to identify the polymorphism of oils and fats and to confirm thermal events during phase transitions (Keller et al., 1996). X-ray diffraction studies have been used to identify phase transitions and the polymorphism of cocoa butter as reported by several authors (Loisel et al., 1998, Marangoni and Narine, 2002; Marangoni and McGauley, 2003; Mazzanti et al., 2003; MacMillan et al., 2002, Schenk and Peschar, 2004; Maleky and Marangoni, 2008; Rousseau and Sonwai, 2008).

The objective of this study is to evaluate the physical properties of pre-crystallized mixtures of cocoa butter and cupuassu fat by using the snap test, melting point, solid fat content curve and x-ray diffraction techniques.

\section{MATERIALS AND METHODS}

\subsection{Material}

Deodorized cocoa butter (mixture of Brazilian and Indonesian cocoa butter supplied by Barry Callebaut Brasil S/A, Bahia, Brazil).

Natural cupuassu fat from the Amazonian region supplied by Aboissa Óleos Vegetais, (São Paulo, Brazil). Before use, the natural cupuassu fat was neutralized to a final acidity of $0.04 \%$.

The experiments were conducted using eight (8) different proportions $(0,5,10,15,20,25,30$ and $100 \%$ ) of cupuassu fat and cocoa butter as presented in Table 1.

\subsection{Methods}

\section{Triacylglycerol composition}

The triacylglycerol composition was determined using an Agilent 6850 gas chromatograph. A 150m length, $0.25 \mathrm{~mm}$ internal diameter DB 17 (50\% phenyl methyl polysiloxane) column was used with the following column temperature program: initial temperature $250^{\circ} \mathrm{C}$ raised at the rate of $5.0^{\circ} \mathrm{C} / \mathrm{min}$ to a final temperature of $350^{\circ} \mathrm{C}$, where it was held for $20 \mathrm{~min}$. The detector temperature was $375^{\circ} \mathrm{C}$ and the injector temperature was $360^{\circ} \mathrm{C}$. The carrier gas was helium and the sample concentration was $20 \mathrm{mg} / \mathrm{mL}$ diluted in tetrahydrofurane, with at least two repetitions for each mixture.

\section{Pre-crystallization}

Pre-crystallization was conducted in a lab scale glass jacketed vessel reactor $(700 \mathrm{~mL})$ coupled to a stirring system. The fat mixture temperature was

Table 1

Denomination and proportion of the mixtures of cocoa butter and cupuassu fat, rupture tension of fat in bar samples after storage and melting points using a differential scanning calorimeter

\begin{tabular}{ccccc}
\hline \multicolumn{2}{c}{$\begin{array}{c}\text { Proportion (\%) } \\
\text { Cocoa butter }\end{array}$} & Samples & $\begin{array}{c}\text { Rupture tension } \\
\mathbf{k g}_{\mathbf{f}} / \mathbf{c m}^{2}\end{array}$ & Melting point $\left({ }^{\circ} \mathbf{C}\right)$ \\
\hline 100 & 0 & CB100 & $2.48 \pm 0.15^{\mathrm{ab}}$ & $35.28 \pm 0.51$ \\
95 & 5 & CUP5 & $2.60 \pm 0.30^{\mathrm{a}}$ & $35.36 \pm 0.28$ \\
90 & 10 & CUP10 & $2.76 \pm 0.25^{\mathrm{a}}$ & $35.33 \pm 0.02$ \\
85 & 15 & CUP15 & $2.69 \pm 0.15^{\mathrm{a}}$ & $34.94 \pm 0.03$ \\
80 & 20 & CUP20 & $2.21 \pm 0.25^{\mathrm{bc}}$ & $34.75 \pm 0.05$ \\
75 & 25 & CUP25 & $2.13 \pm 0.12^{\mathrm{bc}}$ & $34.56 \pm 0.10$ \\
70 & 30 & CUP30 & $1.90 \pm 0.14^{\mathrm{c}}$ & $34.30 \pm 0.05$ \\
0 & 100 & CUP100 & $1.08 \pm 0.06^{\mathrm{d}}$ & $34.62 \pm 0.10$ \\
\hline
\end{tabular}

$\mathrm{a}, \mathrm{b}, \mathrm{c}$ and d differ statistically according to Tukey test with $95 \%$ reliability. For rupture tension, nominal cross section area is $2.2 \mathrm{~cm}{ }^{2}$. 
controlled using two recirculating water baths. The mixture was initially stirred at 96rpm and heated to $40^{\circ} \mathrm{C}$ to remove any crystal remains, and then cooled at a rate of $2.0^{\circ} \mathrm{C} / \mathrm{min}$ until its crystallization temperature of $24^{\circ} \mathrm{C}$. The sample was kept at this temperature for 8 minutes and re-heated to $31^{\circ} \mathrm{C}$ to remove unstable crystals, and to complete the tempering cycle.

After pre-crystallization, the melted fat mixture was poured into molds $(8.2 \times 2.5 \times 0.7 \mathrm{~cm})$ and cooled down to $12^{\circ} \mathrm{C}$ in an $8 \mathrm{~m}$ long tunnel using convective forced air. The residence time of the product in the tunnel was 23 minutes. After cooling, the samples were demolded, wrapped manually with aluminum foil and transferred to a $24 \pm 0.5^{\circ} \mathrm{C}$ temperature controlled chamber, and kept for a period of 15 days to promote crystal network stabilization. After this period, the samples were submitted to rupture force, melting point and X-Ray diffraction determinations.

\section{Rupture Tension}

A Universal TA-XT2i texturometer (Stable Micro Systems, England) with an HDP/3PB - Three Point Bend Rig probe was used to perform the snap test on the bars. The determinations were performed according to the methodology described by Jorge et al., (1999). The conditions used were: distance between bar supports: $6 \mathrm{~cm}$; pre-test velocity: $3 \mathrm{~mm} /$ $\mathrm{sec}$; test velocity: $1.7 \mathrm{~mm} / \mathrm{sec}$; post-test velocity: $10 \mathrm{~mm} / \mathrm{sec}$. The rupture force applied at the center of the bars, expressed in $\mathrm{kg}_{\mathrm{f}}$ was obtained from the force vs deformation graphs. Analyses were made in a $20 \pm 0.5^{\circ} \mathrm{C}$ controlled temperature room using ten (10) repetitions per sample formulations. To avoid the influence of possible variations in the thickness of the bars, the values of the force obtained in each test were divided by the cross section area of each bar and the rupture tension was expressed in $\mathrm{kg}_{\mathrm{f}} / \mathrm{cm}^{2}$.

\section{Melting Point}

A differential scanning calorimeter - DSC-7 (Perkin Elmer, Germany), heat flow type, was used to determine the melting point using the methodology described by Bolliger et al., (1998). About $6 \mathrm{mg}$ of solidified sample were sealed in small aluminium pans and heated at the rate of $2.0^{\circ} \mathrm{C} / \mathrm{min}$ from $20^{\circ} \mathrm{C}$ to $40^{\circ} \mathrm{C}$. Duplicate results were obtained.

\section{Solid fat content (SFC)}

Solid fat content (SFC) was determined following the Cd16b-93 Method described by AOCS (2002), using a Minispec mq20 (ND 1607, Bruker, Germany) nuclear magnetic resonance spectrometer. The fat samples were previously submitted to the following sequential heat treatment: heating to $100^{\circ} \mathrm{C}$, maintained at $100^{\circ} \mathrm{C}$ for $15 \mathrm{~min} ; 5 \mathrm{~min}$ at $60^{\circ} \mathrm{C}$; $90 \pm 5 \mathrm{~min}$ at $0^{\circ} \mathrm{C} ; 40 \pm 0.5 \mathrm{hr}$ at $26^{\circ} \mathrm{C}$ and $90 \pm 5 \mathrm{~min}$ at $0^{\circ} \mathrm{C}$. Solid fat content was measured at the following temperatures: $10^{\circ} \mathrm{C}, 20^{\circ} \mathrm{C}, 21.1^{\circ} \mathrm{C}, 25^{\circ} \mathrm{C}$, $26.7^{\circ} \mathrm{C}, 30.0^{\circ} \mathrm{C}, 33.3^{\circ} \mathrm{C}$ and $35^{\circ} \mathrm{C}$. Before each measurement, the sample was stabilized at the test temperature for 60min. Duplicate analyses were performed.

\section{$X$-Ray diffraction}

$X$-Ray diffraction analyses of the samples were made in a Philips (PW 1710, Holland) diffractometer, using the Bragg-Brentano ( $\theta: 2 \theta)$ geometry with Cuk $\alpha$ radiation, $40 \mathrm{kV}$ tension and $30 \mathrm{~mA}$ current. In the geometry used, the beam of X-ray diffracted by the sample passes through a graphite monochromator crystal located just before the detector. All measurements were obtained at steps of $0.02^{\circ} \mathrm{C}$ in $2 \theta$ with an acquisition time of $2 \mathrm{sec}$. The analyses were performed on fat samples in their crystallized solid form at an average controlled temperature of $22^{\circ} \mathrm{C}$. X-Ray diffraction pattern curves were obtained for samples of cocoa butter, cupuassu fat and select mixtures with 10,20 and $30 \%$ of cupuassu fat contents.

\section{RESULTS AND DISCUSSION}

\subsection{Triacylglycerol Composition}

The triacylglycerol compositions of the samples of cocoa butter and cupuassu fat are listed in Table 2.

The values in Table 2 show that the triacylglycerols present in larger proportions in cocoa butter are POS, SOS and POP, representing $78.2 \%$ of the total triacylglycerols. These triacylglycerols are responsible for the well defined crystallization behavior of cocoa butter. Cupuassu fat did not contain POP or PliP, but high contents of SOS and also $2.13 \%$ of POP $+\mathrm{PliP}$ and $\mathrm{SOO}+\mathrm{OOO}(57.8 \%)$. On the other hand, cupuassu fat showed triacylglycerols of the SOA and OOA types, with amounts of $11.87 \%$ and $10.20 \%$ respectively, which were not identified in cocoa butter. Cupuassu fat presents a high content of symmetrical triacylglycerol of the SUS type (saturated, unsaturated, saturated), which can provide crystallization patterns similar to that of cocoa butter, while the SOO, OOA and OOO triacylglycerols may be responsible for its softness (Gilabert-Escrivá et al., 2002).

\subsection{Rupture Tension}

Snap tests results of the evaluated samples are shown in Table 1.

The values obtained indicate that sample mixtures containing up to $25 \%$ cupuassu fat present snap values that are statistically similar to those of $100 \%$ cocoa butter which show a rupture tension of $2.48 \mathrm{~kg}_{\mathrm{f}} / \mathrm{cm}^{2}$.

The similarity in snap values confirms that with proper pre-crystallization conditioning, these mixtures can be used in the manufacturing of 
Table 2

Triacylglycerol composition of cocoa butter and cupuassu fat

\begin{tabular}{cccc}
\hline & & \multicolumn{2}{c}{$\%$ of area on chromatogram } \\
\hline Number of Carbons & Triacylglycerol & Cocoa butter & Cupuassu fat \\
\hline \multirow{2}{*}{ C50 } & POP & $15.80 \pm 0.16$ & - \\
& PliP & $4.63 \pm 0.30$ & $2.13 \pm 0.40$ \\
C52 & POP+PliP & - & - \\
& POO & $40.12 \pm 0.45$ & $7.52 \pm 0.56$ \\
& PSS+POS & $8.61 \pm 1.44$ & $10.46 \pm 0.66$ \\
C54 & SOS & - & $27.54 \pm 3.86$ \\
& SOO & $22.30 \pm 0.70$ & - \\
& SOO+OOO & $8.54 \pm 0.44$ & $30.28 \pm 3.73$ \\
C56 & SOA & - & $11.87 \pm 0.52$ \\
& OOA & - & $10.20 \pm 0.11$ \\
\hline
\end{tabular}

--- Not found; P - Palmitic, O - Oleic, li -Linoleic, S - Stearic, A - Arachidic

chocolates. The lowest value for rupture tension was observed with the samples containing only cupuassu fat. The decreasing trend of the mechanical resistance observed with the sample containing increasing proportions of cupuassu fat can be attributed to differences between cocoa butter and cupuassu fat fatty acids and triacylglycerol profiles, especially in relation to SOO, OOO and SOA. The snap resistances of chocolates is related to the tempering process and to the ingredients used in the formulation. Thus, in the manufacturing of chocolates using alternative fats such as cupuassu fat, the crystallization parameters should be adjusted for each composition in order to ensure adequate hardness of the final product. Cohen et al., (2004) used 17\% cupuassu liquor and $5 \%$ cupuassu fat added to $17 \%$ cocoa liquor and $5 \%$ cocoa butter in their milk chocolate formulation. Using a pre-crystallization temperature of $29.5^{\circ} \mathrm{C}$ and a tempering time of $7.5 \mathrm{~min}$, they produced chocolate bars with rupture tension of the order of $1.96 \mathrm{~kg}_{\mathrm{f}} / \mathrm{cm}^{2}$, a value which is similar to the rupture tension of the sample with $30 \%$ cupuassu fat shown in Table 1.

\subsection{Melting Point}

The melting point obtained by differential scanning calorimetry of $100 \%$ cocoa butter, $100 \%$ cupuassu fat and of the sample mixtures are presented in Table 1.

The value of the melting point of cocoa butter obtained in this study is close to the values obtained by other researchers (Undurraga et al., 2001; Dhonsi and Stapley 2005; Himawan et al., 2006). The mixtures CUP5 and CUP10 showed melting points which are very close to that of $100 \%$ cocoa butter. A slight lowering trend for the melting point of CUP15 (15\% of cupuassu fat) to CUP30 (30\% cupuassu fat) can be observed, with the lowest value of $34.3^{\circ} \mathrm{C}$ corresponding to CUP30. The difference between the melting point of cupuassu fat and cocoa butter, only $0.66^{\circ} \mathrm{C}$, is, in fact, very small. According to Ali et al., (2001), the melting of cocoa butter occurs in a narrow zone between $27^{\circ} \mathrm{C}$ and $33^{\circ} \mathrm{C}$ and is essentially complete at $35^{\circ} \mathrm{C}$. Studies done by Wille and Lutton (1966), Chapman (1971) and Keller et al., (1996), showed that the beta polymorphic form in cocoa butter has melting points varying from $29^{\circ} \mathrm{C}$ to $35^{\circ} \mathrm{C}$. Based on these data, it can be assumed that the crystallization procedure used for cocoa butter, cupuassu fat and the sample mixtures in this study was sufficient to induce the beta crystalline form.

\subsection{Solid Fat Content (SFC)}

Solid fat content (SFC) determined for the fats and their mixtures are shown in Figure 1.

The solid fat content at $25^{\circ} \mathrm{C}$ reflects the hardness of the fat. The higher this value, the harder the fat is at this temperature. Figure 1 shows that $100 \%$ cupuassu fat has the lowest SFC. For mixtures of up to $20 \%$ cupuassu fat in cocoa butter, the behavior of the curves is close to that

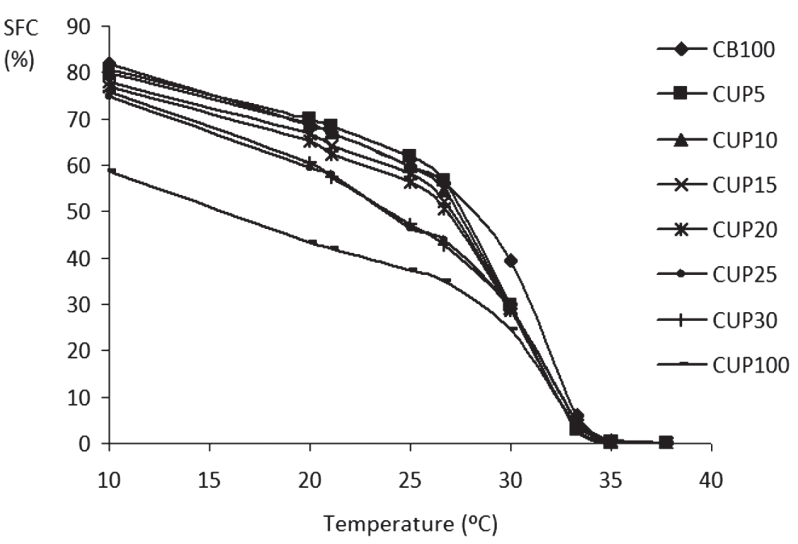

Figure 1

Solid fat contents (SFC) of cocoa butter, cupuassu fat and their mixtures at different temperatures. 
of the curve of $100 \%$ cocoa butter. A considerable reduction in the SFC was observed in samples with $25 \%$ and $30 \%$ of cupuassu fat. Chocolates formulated with these proportions of cupuassu fat require an adjustment of the tempering process so as to adequately induce the formation of beta type crystal nuclei which have higher thermodynamic stability. Lannes et al., (2003) studied the SFC curves in mixtures of cocoa butter and cupuassu fat and also observed that the cupuassu fat has a lower SFC curve compared to $100 \%$ cocoa butter. They also observed that the addition of $30 \%$ cupuassu fat to cocoa butter significantly lowered the SFC at $25^{\circ} \mathrm{C}$. Figure 1 indicated that at $35^{\circ} \mathrm{C}$ all samples presented SFC values which are very close to zero. This corresponds to another important attribute of chocolate since the presence of solid fats at temperatures higher than $35^{\circ} \mathrm{C}$, known as the "fatty residue", is easily detected during the sensory evaluation.

\subsection{X-Ray Diffraction}

The X-ray diffraction curves for cocoa butter, cupuassu fat and some sample mixtures are given in Figure 2.

Figure 2 shows that the diffraction curves obtained for cocoa butter and cupuassu fat are very similar. The main peak for cocoa butter was observed at $19.48^{\circ}$. A similar result was obtained by Schenk and Peschar (2004) and Schenk et al., (2006). They identified 5 polymorphic forms in cocoa butter obtained from different sources. They

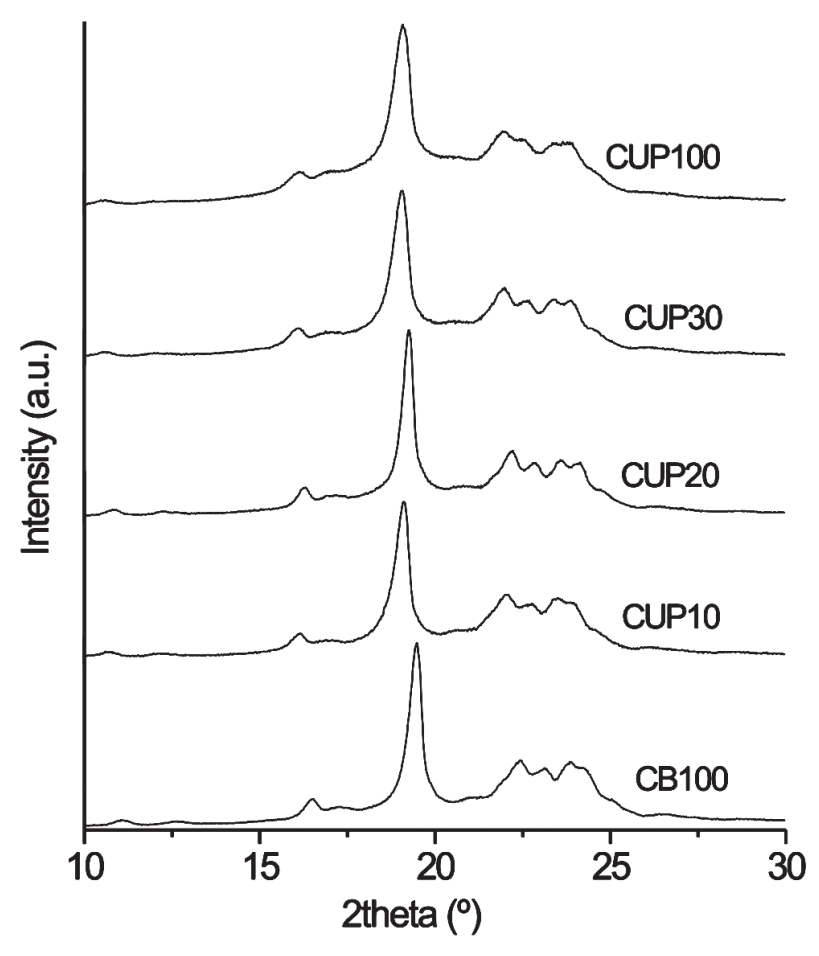

Figure 2

X-ray diffraction curves obtained for cocoa butter, cupuassu fat and CUP10, CUP20 and CUP30. also found the presence of a main peak around $19.5^{\circ}$ in a sample of cocoa butter from Bahia, Brazil and concluded that this behavior was caused by the beta crystalline form. The beta crystalline form was also identified by means of X-ray diffraction by Marangoni and Narine (2002), who studied cocoa butter which was crystallized at $22^{\circ} \mathrm{C}$ and held at this temperature for 20 days. The X-ray diffraction curves they obtained are very similar to those obtained in this study. For cupuassu fat, the main peak was observed at $19.08^{\circ}$, which is very close to that of cocoa butter. The diffraction curves of samples with 10, 20 and $30 \%$ cupuassu fat did not vary significantly from the diffraction curves of cocoa butter. Analyzing the shape of the curves and comparing the behavior of the peaks of cocoa butter and of cupuassu fat, it is possible to infer that the crystalline form present in the pure fat samples studied and in the mixtures is the beta form. This confirms that the conditions used for the tempering were adequate for the formation of this type of crystal. The similarity between the diffraction patterns of cocoa butter and cupuassu fat was expected since both showed similar triacylglycerol composition and, botanically, both belong to the same theobroma species.

\section{CONCLUSIONS}

Mixtures of cocoa butter (Bahia + Indonesian blend) with cupuassu fat showed chemical and crystallization compatibility. The solid fat content at $25^{\circ} \mathrm{C}$ and the near zero SFC value at $35^{\circ} \mathrm{C}$ together with the results of other determinations confirm that mixtures with up to $20 \%$ cupuassu fat can be used in the formulations of chocolates without significantly changing the physical properties of the final product.

X-ray diffractions together with the results obtained for the melting point indicates that the tempering procedures used for crystallization induces the formation of the beta crystalline form in cupuassu fat as well as in pure cocoa butter and their mixtures.

\section{REFERENCES}

Ali A, Selamat J, Che Man YB, Suria AM. 2001. Effect of storage temperature on texture, polymorphic structure, bloom formation and sensory attributes of filled dark chocolate. Food Chem. 72, 491-497.

AOCS - Official methods and recommended practices of the American Oil Chemists Society. 2002, 5 ed., 2. Chicago.

Bolliger S, Breitschuh B, Stranzinger M, Wagner T, Windhab EJ. 1998. Comparison of precrystallization of chocolate. J. Food Eng. 35, 281-297.

Chapman GM. 1971. Cocoa butter and confectionary fats studies using programmed temperature $x$-ray diffraction and differential scanning calorimetry. $J$. American Oil Chem. Soc. 48, 824-830.

Cohen KO, Jackix MNH, Sousa MV. 2004. Otimização do processo de temperagem de produto análogo 
de chocolate ao leite elaborado com amêndoas de cacau e de Cupuaçu. Braz. J. Food Tech. 7, 115-127.

Czerniak AS, Karlovits G, Lach M, Szlyk E. 2005. X-ray diffraction and differential scanning calorimetry studies of $\beta^{\prime} \rightarrow \beta$ transitions in fat mixtures. Food Chem. 92, 133-141.

Dhonsi D, Stapley AGF. 2005. The effect of shear rate, temperature, sugar and emulsifier on the tempering of cocoa butter. J. Food Eng. 77, 936-942.

Gilabert-Escrivá MV, Gonçalves LAG, Silva CRS, Figueira A. 2002. Fatty acid and triacylglycerol composition and thermal behaviour of fats from seeds of Brazilian Amazonian Theobroma species. J. Sci. Food and Agric. 82, 1425-1431.

Himawan C, Starov VM, Stapley AGF. 2006. Thermodynamic and kinetic aspects of fat crystallization. Advances in Colloid and Interface Sci. 122, 3-33.

Jorge MC, Rodríguez I, Hombre R. 1999. Evaluation of an instrumental method of texture analysis for quality control of chocolate bars. Alimentaria 36, 73-76.

Keller G, Lavigne F, Loisel C, Ollivon M, Bourgaux C. 1996. Investigation of the complex thermal behavior of fats - combined DSC and X-ray diffraction techniques. J. Thermal Analysis 47, 1545-1565.

Lannes SCS, Medeiros ML, Gioielli LA. 2003. Physical interactions between cupuassu and cocoa fats. Grasas y Aceites 54, 253-258.

Loisel C, Keller G, Lecq G, Bourgaux C, Ollivon M. 1998. Phase transitions and polymorphism of cocoa butter. J. American Oil Chem. Soc. 75, 425-439.

Macmillan SD, Roberts KJ, Rossi A, Wells MA, Polgreen MC, Smith IH 2002. In situ small angle x-ray scattering (saxs) studies of polymorphism with the associated crystallization of cocoa butter fat using shearing conditions. Crystal Growth Design. 2, 221-226.

Maleky F, Marangoni AG. 2008. Process development for continuous crystallization of fat under laminar shear. J. Food Eng. 89, 399-407.

Marangoni AG, Narine SS. 2002. Identifying key structural indicators of mechanical strength in networks of fat crystals. Food Res. Int. 35, 957-969.

Marangoni AG, Mcgauley SE. 2003. Relationship between crystallization behavior and structure in cocoa butter. Crystal Growth Design. 3, 95-108.
Martínez DP, Salas CA, Alonso MC, Alvarado ED, Vázquez JFT. 2007. The cooling rate effect on the microstructure and rheological properties of blends of cocoa butter with vegetable oils. Food Res. Int. 40, 47-62.

Mazzanti G, Guthrie SE, Sirota EB, Marangoni AG, Idziak SHJ. 2003. Orientation and phase transitions of fat crystals under shear. Crystal Growth Design. 3, 721-725.

Medeiros ML, Ayrosa AMIB, Pitombo RNM, Lannes SCS. 2006. Sorption isotherms of cocoa and cupuassu products. J. Food Eng. 73, 402-406.

Minifie BW. 1989. Chocolate, cocoa and confectionary science and technology. 3ed. Chapman \& Hall: New York.

Oliveira AM, Pereira NR, Marsaioli Jr. A, Augusto F. 2004. Studies on the aroma of cupuassu liquor by headspace solid-phase microextraction and gás chromatography. J. Chromat. A. 1025, 15-124.

Piska I, Zárubová M, Louzecký T, Karami H, Filip V. 2005. Properties and crystallization of fat blends. J. Food Eng. 77, 433-438.

Rousseau D, Sonwai S. 2008. Influence of the dispersed particulate in chocolate on cocoa butter microstructure and fat crystal growth during storage. Food Biophy. 3, 273-278.

Schenk H, Peschar R. 2004. Understanding the structure of chocolate. Rad. Physics and Chem. 71, 829-835.

Schenk H, Visser P, Peschar R. 2006. Alternative precrystallization of cocoa butter. The Manufac. Conf. 86, 67-72.

Silva JC, Plivelic TS, Herrera ML, RuscheinskyBreternitz N, Kieckbusch TG, Luccas V, Torriani IL. 2009. Polymorphic phases of natural fat from cupuassu beans: a waxs/saxs/dsc study. Crystal Growth Design. 9, 6155-5163.

Undurraga D, Markovits A, Erazo S. 2001. Cocoa butter equivalent trough enzymic interesterification of palm oil midfraction. Proc. Biochem. 36, 933-939.

Wille RL, Lutton ES. 1966. Polymorphism of cocoa butter. J. American Oil Chem. Soc. 43, 491-496.

Recibido: $17 / 3 / 10$ Aceptado: 20/5/10 